\title{
梁フランジ幅が H 形断面柱スチフナ補強部の降伏耐力に及ぼす影響 \\ INFLUENCE OF BEAM FLANGE WIDTH ON YIELD STRENGTH OF BEAM FLANGE-TO-WIDE FLANGE COLUMN CONNECTIONS WITH TRANSVERSE STIFFENERS
}

\author{
田川 浩*，劉 翠 平** \\ Hiroshi TAGAWA and Cuiping LIU
}

\begin{abstract}
In wide-flange steel column-to-beam connections, transverse stiffeners are often used to prevent the local failure of columns caused by concentrated beam-flange force. It is well-known that the stiffeners work insufficiently when the beam-flange width is relatively narrow due to the stress concentration to the inner parts of the stiffeners. This paper investigates the influence of beam flange width on the connection strength. The strength formulae of the narrow beam-flange to column connections reinforced with transverse stiffeners are derived by applying the yield line theory. The relationship between the beam-flange width and the strength is examined. The strength reduction is predicted for connections with narrow beam-flanges. Six loading tests and many finite element analyses are performed for the local connection models. The load-displacement relationships and strain distributions on stiffeners and columns are monitored. The results show the validity of the strength prediction and the failure mechanisms used in deriving the strength formulae.
\end{abstract}

Keywords: Beam-to-column Connection, Local Web Yielding, Stiffener, Strength Formula, Yield Line Theory, Test 柱梁接合部，ウェブ局部降伏，スチフナ，耐力評価式，降伏線理論，実験

\section{1 はじめに}

$\mathrm{H}$ 形鎆柱と $\mathrm{H}$ 形鋼梁の溶接接合部では，柱貫通形式の場合，梁フ ランジからの集中荷重による柱の局部破壊を防ぐため水平スチフナ により補強する場合が多い。水平スチフナの必要寸法は, スチフナ が無い場合の柱ウェブ局部降伏耐力を考慮し, 水平スチフナに付与 すべき耐力を算出することにより決定する ${ }^{1) \sim 4) 。 と こ ろ て ゙ ， ス チ フ ~}$ ナ幅に対して，梁フランジ幅が比較的小さいときには，図 1(a)に示 すようにスチフナの応力分布が不均一になり，スチフナが全幅機能 せず，耐力が减少する可能性があることが知られている。このとき， 図 1(b)のような応力の広がりを仮定してスチフナの有効幅を算定し， スチフナ補強部の耐力を算定する場合がある ${ }^{5)}$ 。図 1(b)では, 忘力 が広がる方向を 45 度と仮定しているが,この方向は柱フランジやウ ェブの厚さおよび梁フランジの幅などの組み合わせにより変化する ものと考えられる。

本論文では，梁フランジ幅が柱スチフナ補強部の耐力に及ぼす影 響を，柱や梁の寸法を考慮して検討するための手法を提示する。ま ず, 梁フランジ幅が狭い場合の崩壊機構を想定し, 降伏線理論に基 づき耐力評価式を導出する。続いて, 引張側梁フランジ接合部を模 擬した試験体を用いて載荷実験を行い，耐力評価式の精度および想 定した崩壊機構の妥当性を確認する。さらに, 合計 168 ケースの有 限要素解析の結果を分析し, 梁フランジ幅減少に伴う耐力低下が的 確に予測できることを示すとともに，スチフナの有効幅について検

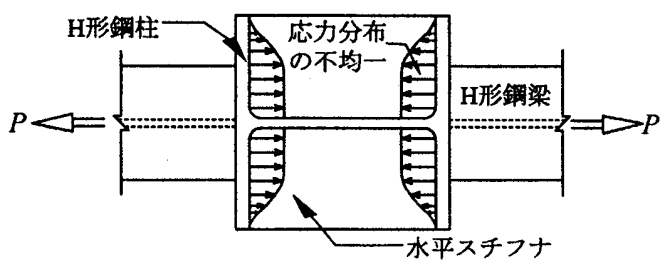

(a) スチフナの応力分布（模式図）

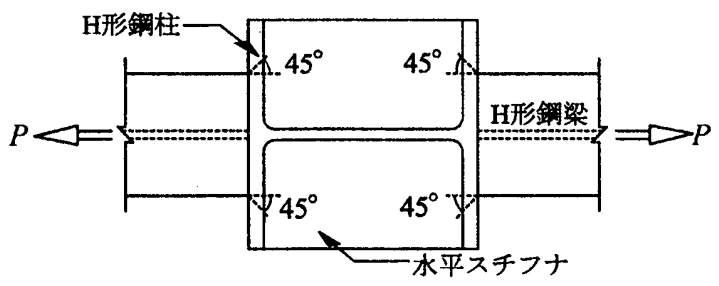

(b) 応力伝達仮定の例

図 1 梁フランジ幅が狭い場合のスチフナ応力分布 討した結果を示す。なお, 既往の研究において, 梁フランジ引張側 または圧縮側を取り出した部分接合部の挙動が柱梁接合部の局部举 動と適合すること 6)，局部耐力に基づく梁端接合部の曲げ耐力評価

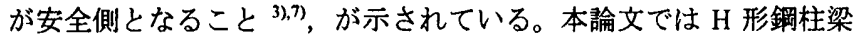
接合部における梁フランジ引張側の局部降伏耐力を検討する。

\section{2 降伏線理論による耐力評価式の導出}

梁フランジ幅が狭くなるのに伴い，崩壊機構が図 2 に示す機構 1
本論文は参考文献10)，11）に加筆修正したものである。

* 名古屋大学大学院環境学研究科 助教授・博士 (工学)

** 名古屋大学大学院環境学研究科 大学院生・修士(工学)
Assoc. Prof., Graduate School of Environmental Studies, Nagoya Univ., Dr. Eng. Graduate Student, Graduate School of Environmental Studies, Nagoya Univ., M. Eng. 
から機構 3 へ変化すると仮定する。これらの機構では梁フランジは 剛体とし，図1に示したようにスチフナ外縁と柱フランジ外縁が一 致する場合を対象とする。なお，梁フランジ幅が十分広い場合の崩 壊機構として，機構 1 では 4 本の平行な降伏線を柱フランジ上に想 定しているのに対して，筆者らは文献 4),8)において，外側の 2 本が 平行ではない実際の崩壊形に近い機構を用いて耐力評価を行ってい る。本論文では，機構 2 および機構 3 の崩壊形との連続性を考慮し て機構 1 の崩壊形を想定する。

\section{1 機構 $1^{33}$}

機構 1 は図 2(a)に示すように，互いに平行な 4 本の降伏線が柱フ ランジに生じ，ウェブに降伏場が生じる。スチフナは一様に塑性変 形する。機構 1 の耐力は文献 3)において森田らにより検討されてお り，耐力評価式は次式で表される。

$$
\begin{aligned}
& { }_{1} P_{y}=2 t_{f} \sqrt{B_{c} t_{w} \sigma_{w y} \sigma_{y}}+t_{b} t_{w} \sigma_{w y}+\left(B_{c}-t_{w}\right) t_{s} \sigma_{s y} \\
& \text { ただし, } \gamma=t_{f} \sqrt{B_{c} \sigma_{y} /\left(t_{w} \sigma_{w y}\right)}
\end{aligned}
$$

ここに, $B_{c}$ : 柱フランジ幅, $t_{f}$ : 柱フランジ厚, $t_{w}$ : 柱ウェブ厚, $t_{b}$ : 梁フランジ厚, $\sigma_{y}$ : 柱フランジ降伏強さ, $\sigma_{w y}$ : 柱ウェブの降伏強さ。

\section{2 機粠 2}

機構 2 を図 2(b)に示す。機構 2 は 10 本の降伏線が柱フランジに生 じ,ウェブに降伏場が生じる。スチフナは全幅にわたり降伏するが， 梁フランジ端部位置より外側での塑性変形量が減少する。

図 2(b)に示すように鋼板に仮想变位 $\delta$ を与えたとき，降伏線 $E E$ $\left(E^{\prime} E^{\prime}\right), F F\left(F^{\prime} F^{\prime}\right)$ の回転角は $\delta / x$, 降伏線 $E E^{\prime}$ の回転角は $2 \delta /\left(B_{c}-B_{b}\right)$, 降伏線 $E F\left(E^{\prime} F^{\prime}\right)$ の回転角は $\delta \sqrt{x^{2}+\left(B_{c}-B_{b}\right)^{2} / 4} /\left\{x\left(B_{c}-B_{b}\right) / 2\right\}$ とな る。 $|F E|=\sqrt{x^{2}+p^{2}+\delta^{2}} \cong \sqrt{x^{2}+p^{2}}$ とし, 柱フランジ上の降伏線に
おける単位長さあたりの全塑性モーメントを $M_{p}$ で表すと，各降伏 線における内力仕事はそれぞれ次のように得られる。

$$
\begin{aligned}
& E_{E E}^{i n}=M_{p} \frac{B_{b} \delta}{x}, E_{F F}^{i n}=M_{p} \frac{B_{c} \delta}{x}, E_{E E^{\prime}}^{i n}=2 M_{p} \frac{t_{b}}{B_{c}-B_{b}} \delta \\
& E_{E F}^{i n}=M_{p} \delta\left(\frac{2 x}{B_{c}-B_{b}}+\frac{B_{c}-B_{b}}{2 x}\right)
\end{aligned}
$$

ウェブ降伏場およびスチフナ降伏場の内力仕事はそれぞれ次のよう に得られる。

$$
E_{Y F W}^{i n}=\left(x+t_{b}\right) t_{w} \sigma_{w y} \delta, E_{Y F S}^{i n}=\left(\frac{B_{c}+B_{b}}{2}-t_{w}\right) t_{s} \sigma_{s y} \delta
$$

式(3)〜(8)により内部仮想仕事の合計 $E_{2}^{i n}$ は次式のように得られる。

$$
E_{2}^{i n}=2 E_{E E}^{i n}+2 E_{F F}^{i n}+4 E_{E F}^{i n}+2 E_{E E^{\prime}}^{i n}+E_{Y F W}^{i n}+E_{Y F S}^{i n}
$$

梁フランジに作用する荷重を. $P$ で表すと，外力仕事 $E_{2}^{e x}$ は次式で表 すことができる。

$E_{2}^{e x}=P \delta$

仮想仕事の原理から $E_{2}^{i n}=E_{2}^{e x}$ が成立する。よって, $M_{p}=t_{f}^{2} \sigma_{y} / 4$ を 考虑すると，崩買荷重の上界は次式のように得られる。

$$
\begin{aligned}
& { }_{2} \hat{P}_{y}=t_{f}^{2} \sigma_{y}\left(\frac{B_{c}}{x}\right)+\left(\frac{2 t_{f}^{2} \sigma_{y}}{B_{c}-B_{b}}+t_{w} \sigma_{w y}\right) x \\
& +t_{b} t_{w} \sigma_{w y}+\frac{t_{f}^{2} \sigma_{y} t_{b}}{B_{c}-B_{b}}+\left(\frac{B_{c}+B_{b}}{2}-t_{w}\right) t_{s} \sigma_{s y}
\end{aligned}
$$

式(11)において相加平均 $\geq$ 相乗平均の関係を考虑して, 次式を得る。

$$
\begin{aligned}
& { }_{2} \hat{P}_{y} \geq 2 t_{f} \sqrt{B_{c} \sigma_{y}\left[2 t_{f}^{2} \sigma_{y} /\left(B_{c}-B_{b}\right)+t_{w} \sigma_{w y}\right]}+t_{b} t_{w} \sigma_{w y} \\
& +t_{f}^{2} \sigma_{y} t_{b} /\left(B_{c}-B_{b}\right)+\left[\left(B_{c}+B_{b}\right) / 2-t_{w}\right] t_{s} \sigma_{s y}={ }_{2} P_{y}
\end{aligned}
$$

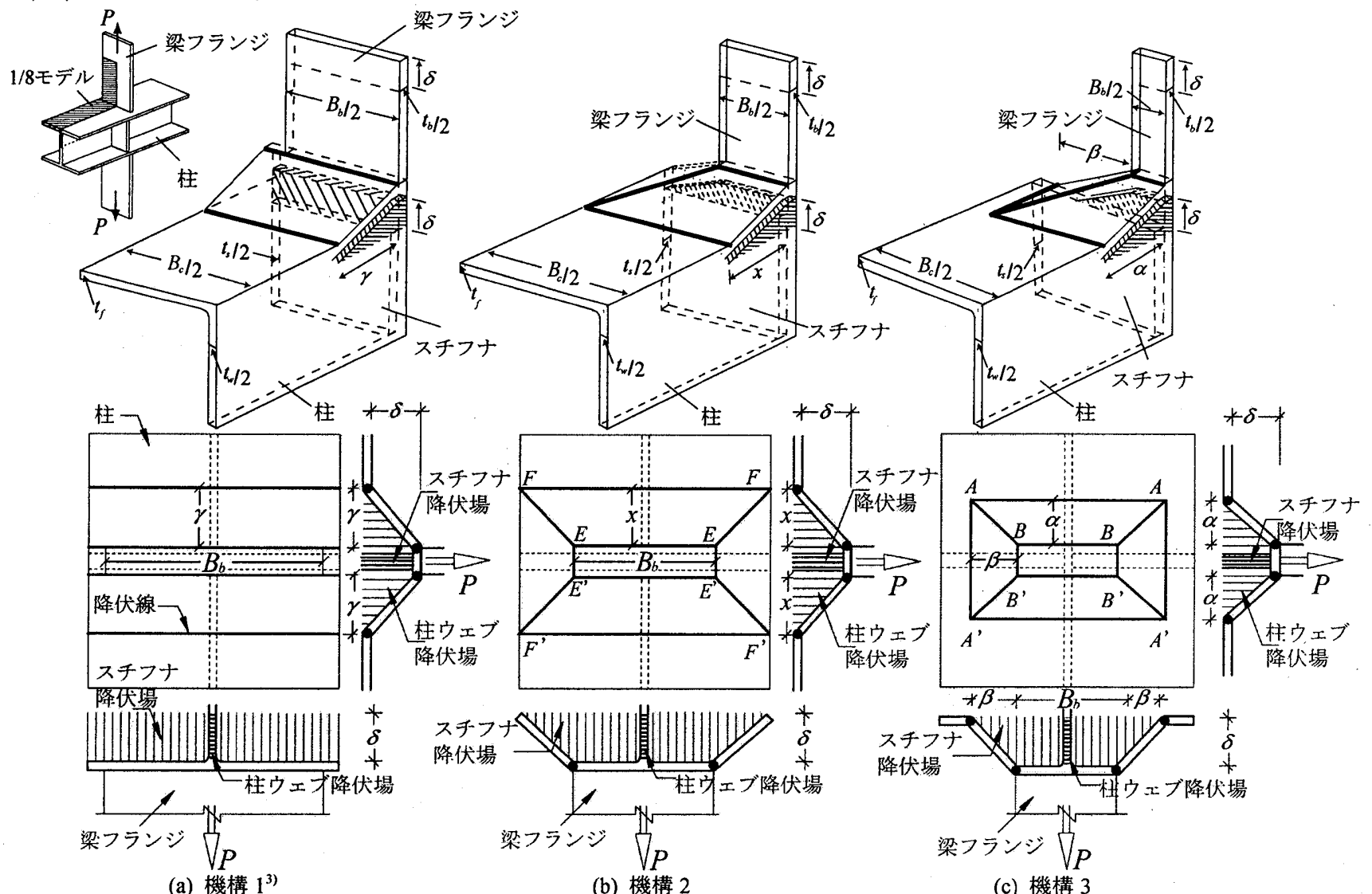

図 2 スチフナ補強された梁フランジー $\mathrm{H}$ 形鋼柱接合部の崩壊機構（上段：1/8 モデル） 
なお, 式(12)に示すように ${ }_{2} \hat{P}_{y}$ の最小値を ${ }_{2} P_{y}$ で表す。 ${ }_{2} P_{y}$ をちる $x$ は次式で表される。

$$
x=t_{f} \sqrt{B_{c} \sigma_{y}\left(B_{c}-B_{b}\right) /\left(2 t_{f}^{2} \sigma_{y}+t_{w} \sigma_{w y}\left(B_{c}-B_{b}\right)\right)}
$$

\section{3 機構 3}

機構 3 を図 2(c)に示す。機構 3 は 12 本の降伏線が柱フランジに生 じ, ウェブに降伏場が生じる。スチフナ外縁に近い領域は塑性変形 しない。図 2(c)に示すように鋼板に仮想変位 $\delta$ を与えたとき，降伏 線 $A A\left(A^{\prime} A^{\prime}\right), B B\left(B^{\prime} B^{\prime}\right)$ の回転角は $\delta / \alpha$, 降伏線 $B B^{\prime}\left(A A^{\prime}\right)$ の回転角は $\delta / \beta$, 降伏線 $A B\left(A^{\prime} B^{\prime}\right)$ の回転角は $\delta \sqrt{\alpha^{2}+\beta^{2}} /(\alpha \beta)$ となる。柱フラ ンジ上の降伏線における単位長さあたりの全塑性モーメントを $M_{p}$ で表すと，降伏線 $A A\left(A^{\prime} A^{\prime}\right), B B\left(B^{\prime} B^{\prime}\right), A B\left(A^{\prime} B^{\prime}\right), A A^{\prime}, B B^{\prime}$ における 内力仕事はそれぞれ次のように得られる。

$$
\begin{aligned}
& E_{A A}^{i n}=\left(B_{b}+2 \beta\right) M_{p} \frac{\delta}{\alpha}, E_{B B}^{i n}=B_{b} M_{p} \frac{\delta}{\alpha}, E_{A B}^{i n}=M_{p} \delta\left(\frac{\alpha}{\beta}+\frac{\beta}{\alpha}\right) \\
& E_{A A^{\prime}}^{i n}=M_{p} \frac{t_{b}+2 \alpha}{\beta} \delta, E_{B B^{\prime}}^{i n}=M_{p} \frac{t_{b}}{\beta} \delta
\end{aligned}
$$

ウェブ降伏場およびスチフナ降伏場の内力仕事はそれぞれ次のよう に得られる。

$$
E_{Y F W}^{i n}=\left(\alpha+t_{b}\right) t_{w} \sigma_{w y} \delta, E_{Y F S}^{i n}=\left(B_{b}-t_{w}+\beta\right) t_{s} \sigma_{s y} \delta
$$

式(14)〜(20)により内部仮想仕事の合計 $E_{3}^{\text {in }}$ は次式のように得られる。

$$
E_{3}^{i n}=2 E_{A A}^{i n}+2 E_{B B}^{i n}+4 E_{A B}^{i n}+2 E_{A A^{\prime}}^{i n}+2 E_{B B^{\prime}}^{i n}+E_{Y F W}^{i n}+E_{Y F S}^{i n}
$$

梁フランジに作用する荷重を $P$ で表す。外力仕事 $E_{3}^{e x}$ は次式となる。

$$
E_{3}^{e x}=P \delta
$$

仮想仕事の原理から $E_{3}^{i n}=E_{3}^{e x}$ が成立する。以上より, $M_{p}=t_{f}^{2} \sigma_{y} / 4$ を 考虑すると，崩壊荷重の上界は次式のように得られる。

$$
\begin{aligned}
& { }_{3} \hat{P}_{y}=t_{f}^{2} \sigma_{y}\left(\frac{B_{b}}{\alpha}+\frac{t_{b}}{\beta}\right)+2 t_{f}^{2} \sigma_{y}\left(\frac{\beta}{\alpha}+\frac{\alpha}{\beta}\right) \\
& +\left(\alpha+t_{b}\right) t_{w} \sigma_{w y}+\left(B_{b}-t_{w}+\beta\right) t_{s} \sigma_{s y}
\end{aligned}
$$

式(23)において相加平均 $\geq$ 相乗平均の関係を考虑して, $\beta=\xi \alpha$ の関 係を用いると，次式を得る。

$$
\begin{aligned}
& { }_{3} \hat{P}_{y} \geq 2 t_{f}\left[\sqrt{\sigma_{y}\left(B_{b}+\frac{t_{b}}{\xi}\right)\left(t_{w} \sigma_{w y}+\xi t_{s} \sigma_{s y}\right)}\right. \\
& \left.+t_{f} \sigma_{y}\left(\frac{1}{\xi}+\xi\right)\right]+t_{b} t_{w} \sigma_{w y}+\left(B_{b}-t_{w}\right) t_{s} \cdot \sigma_{s y}={ }_{3} P_{y} \\
& \text { ただし, } \alpha=t_{f} \sqrt{\sigma_{y}\left(B_{b}+t_{b} / \xi\right) /\left(t_{w} \sigma_{w y}+\xi t_{s} \sigma_{s y}\right)}
\end{aligned}
$$

なお，式(24)に示すように ${ }_{3} \hat{P}_{y}$ の最小值を ${ }_{3} P_{y}$ で表す。 ${ }_{3} P_{y}$ を与える $\alpha$ は式(25)で表される。 ${ }_{3} P_{y}$ が最小となるときの $\xi$ は次式を満足する。

$$
\frac{t_{s} B_{b} \sigma_{y} \sigma_{s y} \xi^{2}-t_{w} t_{b} \sigma_{y} \sigma_{w y}}{2 \xi \sqrt{\sigma_{y}\left(B_{b} \xi+t_{b}\right)\left(t_{w} \xi \sigma_{w y}+\xi^{2} t_{s} \sigma_{s y}\right)}}+t_{f} \sigma_{y}\left(1-\frac{1}{\xi^{2}}\right)=0
$$

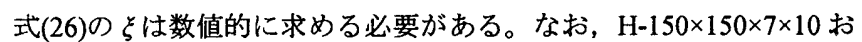
よび H-300×300×10×15 を柱に用いた場合について検討した結果， $=1$ とおけば, 精度 $98 \%$ 程度の解が得られることを確認した。

\section{4 梁フランジ幅による崩壊機構の変化}

機構 1 の耐力評価式 ${ }_{1} P_{y}$ には梁フランジ幅 $B_{b}$ は含まれないが, 耐 力評価式 ${ }_{2} P_{y}$ および ${ }_{3} P_{y}$ は梁フランジ幅 $B_{b}$ の関数になっている。梁フ ランジ幅に対応する ${ }_{1} P_{y},{ }_{2} P_{y},{ }_{3} P_{y}$ の最小值が降伏耐力となることか ら，降伏耐力は次式により評価することができる。

$$
{ }_{\text {eval }} P_{y}=\min \left({ }_{1} P_{y, 2} P_{y}, 3 P_{y}\right)
$$

降伏耐力評価値と梁フランジ幅の関係を図 3 に模式的に示す。こ の模式図は次節以降の結果を参考にして描いたものである。 ${ }_{1} P_{y}$ と ${ }_{2} P_{y}$ が交わる点の梁フランジ幅を $B_{b}{ }^{c}$ で表すと, 梁フランジ幅が $B_{b}{ }^{c}$ より狭くなると降伏耐力が减少する。次式によって表される $B_{b}$ に関 する方程式の解が $B_{b}^{\mathrm{c}}$ となる。

$$
{ }_{1} P_{y}={ }_{2} P_{y}
$$

また, ${ }_{2} P_{y}$ と ${ }_{3} P_{y}$ が交わる点の梁フランジ幅を $B_{b}{ }^{\mathrm{s}}$ で表すと, 次式によ つて表される $B_{b}$ に関する方程式の解が $B_{b}^{\mathrm{s}}$ となる。

$$
{ }_{2} P_{y}={ }_{3} P_{y}
$$

梁フランジ幅が $B_{b}{ }^{\mathrm{s}}$ より狭くなると機構 3 が生じる。

以上より，図 3 に示すように，梁フランジ幅によって生じる崩壊 機構が変化すると予想される。

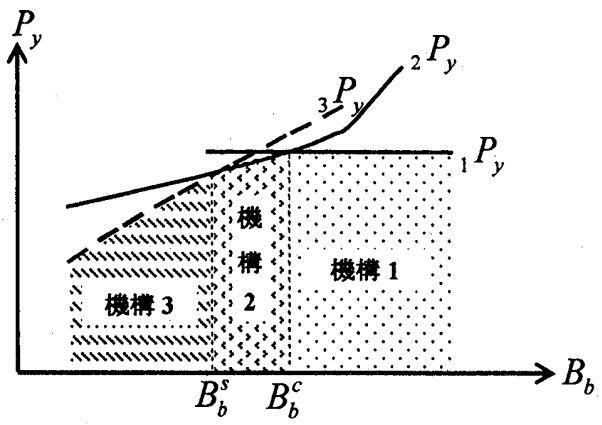

図 3 降伏耐力評価值〜梁フランジ幅の関係（模式図）

\section{3 接合部引張実験}

\section{1 試験体および載荷・計測方法}

試験体は， $\mathrm{H}$ 形鋼柱梁接合部における引張側梁フランジ接合部を モデル化したものである。図 4 および表 1 に示すように, 梁フラン ジ幅 $B_{b}$ が異なる $\mathrm{Al} \sim \mathrm{A} 6$ の 6 体の試験体は, 全て柱が $\mathrm{H}-150 \times 150$ $\times 7 \times 10$ のスチフナ付き引張試験体である。表 1 に耐力評価值も示 す。スチフナはノンスカラップとし，梁フランジを模擬した鋼板の 厚さ $t_{b}$ は破壊を防ぐために十分厚くした。 $\mathrm{H}$ 形鋼と鋼板との溶接は 完全溶込み溶接として，董はつり形式とする。スチフナはサイズ $6 \mathrm{~mm}$ の隅肉溶接で取り付けた。表 2 に材料特性を示す。

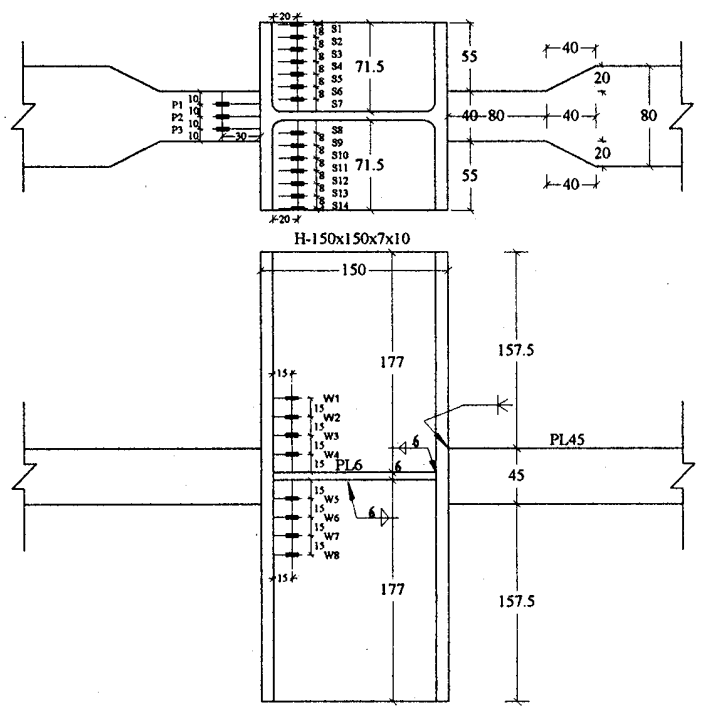

図 4 試験体の形状および歪ゲージ位置（A-1） 
表 1 試験体

\begin{tabular}{|c|c|c|c|c|}
\hline \multirow{2}{*}{$\begin{array}{l}\text { 試 } \\
\text { 験 } \\
\text { 体. }\end{array}$} & \multicolumn{2}{|c|}{ 梁フランジ } & \multirow{2}{*}{$\begin{array}{c}\text { 耐力評価値 } \\
\text { evul } P_{y} \\
(\mathrm{kN}) \\
\end{array}$} & \multirow[b]{2}{*}{ 機構 } \\
\hline & $\begin{array}{c}B_{b} \\
(\mathbf{m m})\end{array}$ & $\begin{array}{c}t_{b} \\
(\mathrm{~mm})\end{array}$ & & \\
\hline $\mathrm{A}-1$ & 40 & 45 & $532.4\left({ }_{3} P_{y}\right)$ & 機構 3 \\
\hline $\mathrm{A}-2$ & 60 & 45 & $566.2\left({ }_{2} P_{y}\right)$ & 機構 2 \\
\hline $\mathrm{A}-3$ & 80 & 45 & $600.5\left({ }_{2} P_{y}\right)$ & 機構 2 \\
\hline $\mathrm{A}-4$ & 100 & 22 & $569.5\left({ }_{1} P_{y}\right)$ & 機構 1 \\
\hline A-5 & 120 & 22 & $569.5\left({ }_{1} P_{y}\right)$ & 機構 1 \\
\hline $\mathrm{A}-6$ & 140 & 22 & $569.5\left({ }_{1} P_{y}\right)$ & 機構 1 \\
\hline
\end{tabular}

表 2 材料特性

\begin{tabular}{|c|c|c|c|}
\hline 材料 & $\begin{array}{c}\text { 降伏強さ } \\
\left(\mathbf{N} / \mathbf{m m}^{2}\right)\end{array}$ & $\begin{array}{c}\text { 引張強さ } \\
\left(\mathbf{N} / \mathbf{m m}^{2}\right)\end{array}$ & $\begin{array}{c}\text { 伸び率 } \\
(\%)\end{array}$ \\
\hline $\begin{array}{c}\mathrm{H}-150 \times 150 \\
{[\mathrm{SN} 400 \mathrm{~B}]}\end{array}$ & $\begin{array}{c}309 \\
426\end{array}$ & $\begin{array}{c}448 \\
457\end{array}$ & $\begin{array}{c}26.75 \\
24.50\end{array}$ \\
\hline $\begin{array}{c}45 \mathrm{~mm} \text { 鍽板 } \\
{[\mathrm{SM} 490 \mathrm{~A}]}\end{array}$ & 378 & 541 & 27.50 \\
\hline $\begin{array}{c}22 \mathrm{~mm} \text { 鋼板 } \\
{[\mathrm{SN} 490 \mathrm{~B}]}\end{array}$ & 375 & 527 & 25.50 \\
\hline $\begin{array}{c}12 \mathrm{~mm} \text { 銅板 } \\
{[\mathrm{SN} 400 \mathrm{~B}]}\end{array}$ & 313 & 446 & 26.28 \\
\hline $\begin{array}{c}6 \mathrm{~mm} \text { 鋼板 } \\
{[\mathrm{SN} 400 \mathrm{~B}]}\end{array}$ & 340 & 451 & 20.25 \\
\hline
\end{tabular}

$\mathrm{H}-150 \times 150$ 上段: フランジ 下段: ウェブ

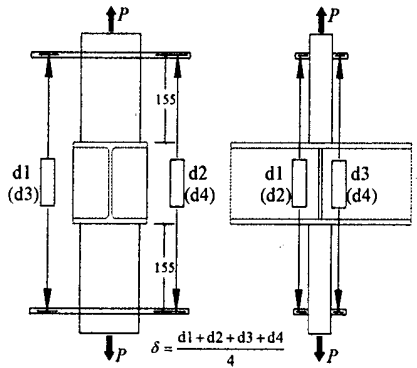

図 5 載荷および変位計測方法

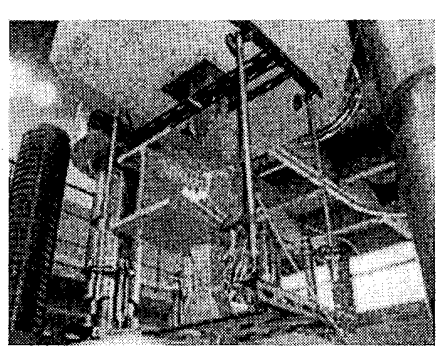

写真 1 載荷状況（試験体 A-1）
図 5 に載荷および変位計測方法を示す。柱フランジ外縁からそれ ぞれ $155 \mathrm{~mm}$ ずつ離れたところの相対变位 $\delta$ を測定する。なお， $\delta$ は 図 5 に示す $\mathrm{d} 1$ 〜 44 の平均值とする。万能試験機により柱フランジの 面外変形が明瞭となった時点まで載荷した。写真 1 は試験体 A-1 の 載荷状況を示す。

\section{2 荷重 変形関係曲線}

図 6 に各試験体の荷重〜变形関係曲線を実線で描く。荷重〜変形 曲線において，接線剛性が初期剛性の $1 / 3$ となる荷重を降伏荷重 ${ }_{t e s} P_{y}$ とし，そのレベルを図中に示す。表 1 に示した降伏耐力の評価值 eval $P_{y}$ も図中に示す。試験体 A-1 の耐力評価值は機構 3, 試験体 A-2 およ び試験体 A-3 の耐力評価値は機構 2, 試験体 A-4 A-6 の耐力評価值 は機構 1 にそれぞれ対応する。ここで，梁フランジ幅 $B_{b}$ および梁フ ランジ厚 $t_{b}$ には余盛サイズを考慮して耐力評価值を算出している。 いずれのケースも耐力評価值 ${ }_{\text {eval }} P_{y}$ と実験值 ${ }_{\text {test }} P_{y}$ はよく対応してお り， ${ }_{1} P_{y},{ }_{2} P_{y},{ }_{3} P_{y}$ により降伏耐力が良好な精度で評価できることが

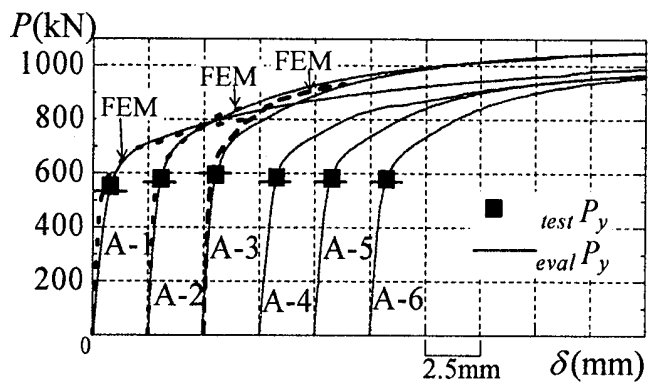

図 6 荷重～変形関倸

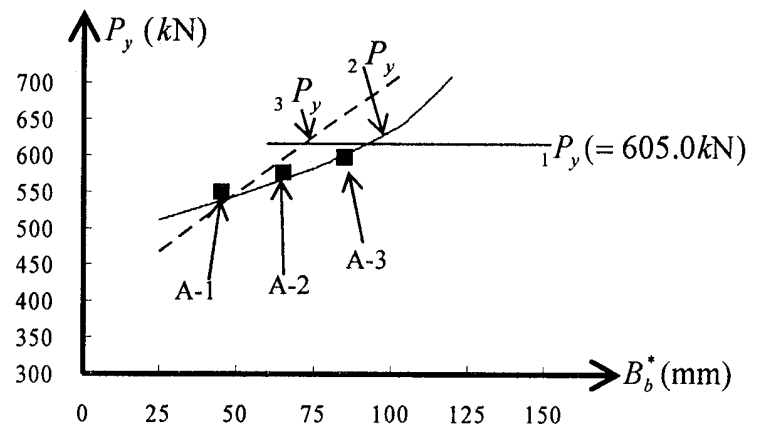

(a) 試験体 $\mathrm{A}-1 \sim \mathrm{A} 3$

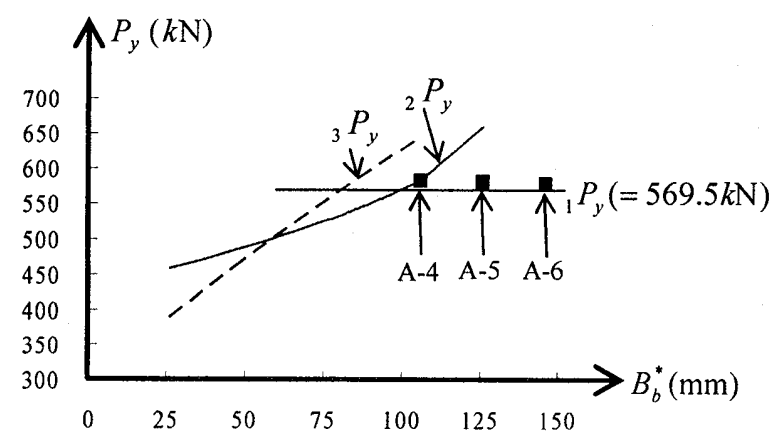

(b) 試験体 A-4 A-6

図 7 降伏耐力〜梁フランジ幅の関係

分かる。ただし, 機構 1〜機構 3 の耐力評価式では, スチフナの隅 肉溶接および柱フィレットを考慮していない。これらが評価值に及 ぼす影響について付録で考察する。

図 7 に試験体 A-1 A-3 および試験体 A-4〜A-6 について降伏耐力 評価值〜梁フランジ幅の関係曲線と実験時の降伏耐力值 ${ }_{12 S} P_{y}$ を重ね て示す。横軸 $B_{b}{ }^{*}$ は余盛を考虑した梁フランジ幅である。図(a)より 試験体 A-1〜A-3 では梁フランジ幅の減少とともに耐力が減少する こと，図(b)より試験体 A-4〜A-6 はいずれも機構 $\mathrm{i}$ に対応しており， 梁フランジ幅が降伏耐力に影響しないことが確認できる。

\section{3 柱ウェブ, スチフナおよび梁フランジの歪分布}

歪ゲージにより柱ウェブ， スチフナおよび梁フランジの歪分布を 測定した。200kN から $800 \mathrm{kN}$ までの各荷重レベルにおける柱ウェブ

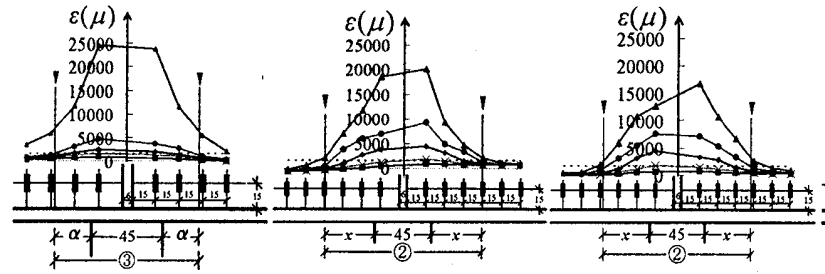

(a) 試験体 A-1 (b) 試験体 A-2 (c) 試験体 A-3

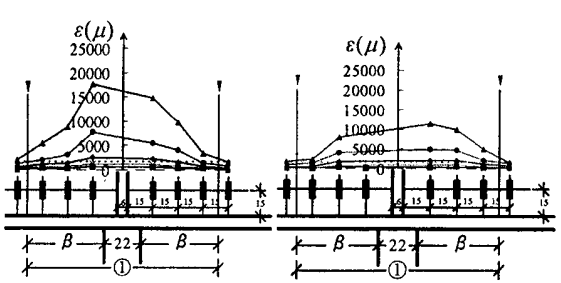

(d) 試験体 A-4

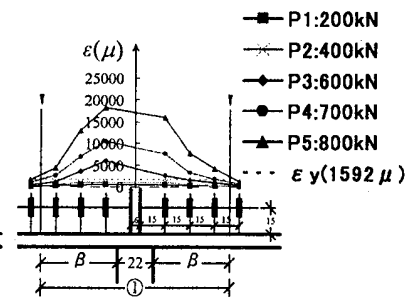

(f) 試験体 A-6 図 8 柱ウェブの歪分布 (1),(2),(3)：機構 1,2,3 の予想降伏範囲) 


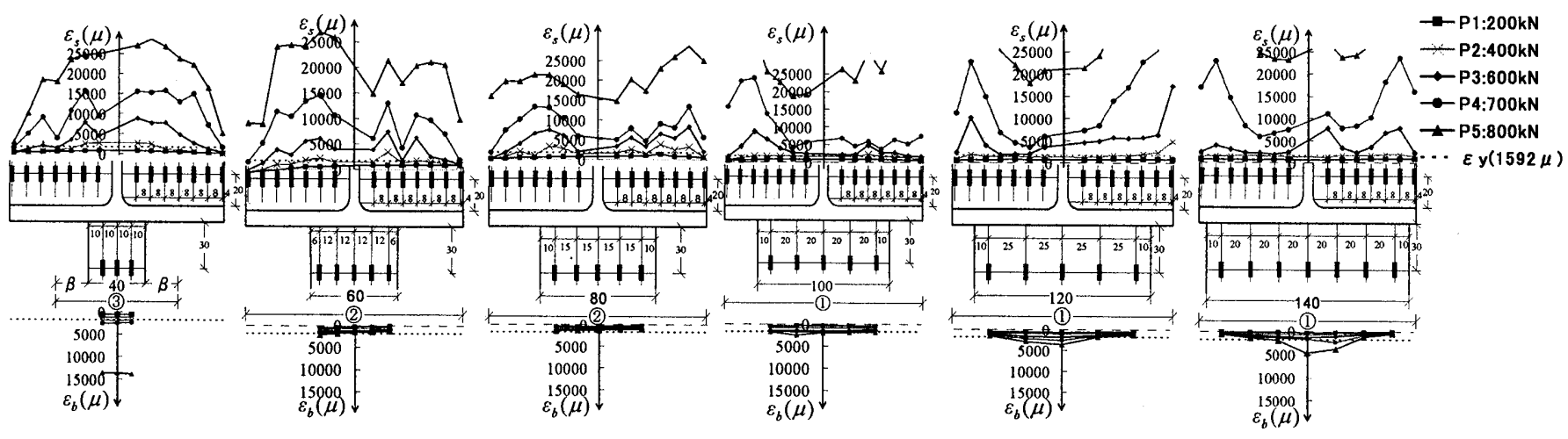

(a) 試験体 A-1

(b) 試験体 A-2

(c) 試験体 A-3

(d) 試験体 A-4

(e) 試験体 A-5

(f) 試験体 A-6

図 9 スチフナおよび梁フランジの歪分布（1(1),(2),(3) : 機構 1,2,3 の予想降伏範囲）

歪分布と予想降伏範囲を図 8 に示す。試験体 A-5 の左から 4 番目の 歪が計測不能となっており,左から 3 番目と 5 番目を直線で結んだ。 試験体 A-1 A-6 のいずれのケースもウェブの予想降伏範囲内（文 印間の領域) で大きく塑性変形している。次に $200 \mathrm{kN}$ から $800 \mathrm{kN}$ ま

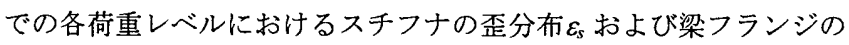
歪分布 $\varepsilon_{b}$ と予想降伏範囲を図 9 に示す。試験体 A-1 では, スチフナ

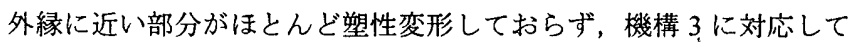
いる。試験体 A-2 および試験体 A-3 はスチフナ全幅にわたり降伏し ているが, 梁フランジ端部より外側での塑性変形量が減少する傾向 があり，機構 2 と対応している。試験体 A-4〜A-6 は概ねスチフナ 全幅にわたり降伏しており, 機構 1 と対応している。また, 試験体 A-1 A-6 において, 降伏荷重付近 $(600 \mathrm{kN})$ の梁フランジの歪分布 がほぼ弾性範囲内にあることが確認できる。

\section{4 実験後の残留変形}

実験後の面外残留変形を測定した。実験前にあらかじめ試験体の 柱フランジに $1 \mathrm{~cm}$ 間隔の格子を描き，実験後に梁フランジを切断し て, 各格子点の面外変形量を測定した。図 10 は, 試験体 A-1 A-3 において実験後の柱フランジ面外残留変形の等高線を細い実線で, 降伏線理論により予想される降伏線位置を太い実線で描いたもので ある。等高線は予想降伏線の外側にも広がっているが，等高線の間 隔から判断すると, 想定した崩壊機構と似ている形状が生じている ことが分かる。写真 2 には, 実験後の残留変形を試験体 A-1 と試験 体 A-2 について示す。
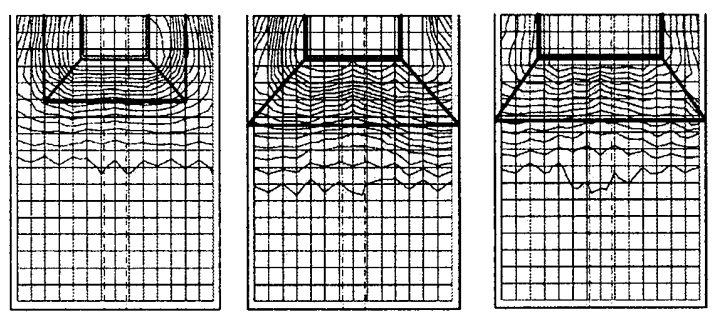

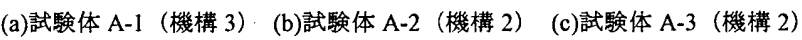
図 10 柱フランジ面外残留変形の等高線および予想降伏線

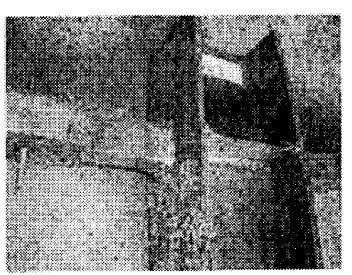

(a) 試験体 A-1

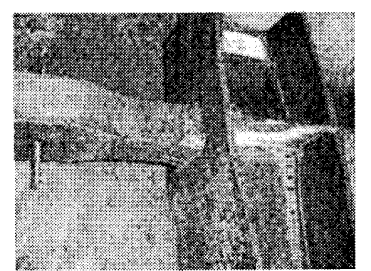

(b) 試験体 A-2
写真 2 実験後の残留変形

\section{4 有限要素解析}

\section{1 解析概要}

図 11 に示す解析対象は, $\mathrm{H}$ 形鋼柱梁接合部における引張側梁フラ ンジ接合部をモデル化したものである。荷重分布およびモデル対称 性を考慮して，1/8 モデルを作成し解析を行った。ここで, 梁フラン ジと柱の溶接部余盛およびスチフナ取り付けの隅肉溶接は考慮しな いが，柱ウェブフィレットは考慮してモデル化した。解析には ANSYS 7.09) を使用し，要素には 8 節点ソリッド要素を用いる。部 材断面の要素分割は板厚方向に 2 分割とし, 応力変化が激しい部分 の分割は細かく行う。メッシュサイズは $5 \mathrm{~mm}$ 以下とする。鋼材の応 カ〜ひずみ関係は von Mises の降伏条件を考え, 材料試験結果を参 考にした multi-linear モデルとする。材料特性のモデル化の例を図 12 に示す。解析で用いた材料特性を表 3 に示す。ヤング係数は $2.05 \times 10^{5}$ $\mathrm{N} / \mathrm{mm}^{2}$, ポアソン比は 0.3 とする。梁フランジを模擬した鋼板は弾 性とする。なお，解析モデルの妥当性を確認するため， 2 節で示し た実験と同じ条件で有限要素解析を行った。図 6 に試験体 A-1 A-3 の解析結果を破線で重ねて示した。A-1 では剛性に差が見られるも のの，耐カレベルではいずれも同等の結果となっている。

\section{2 解析ケース}

次に示す 2 つのケースに対して解析を行う。解析モデルの総数は 168 である。スチフナは柱フランジ全幅に取り付ける。

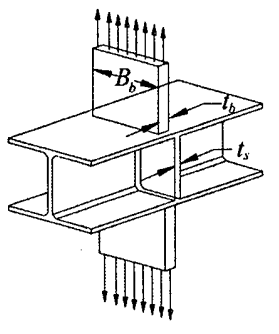

図 11 解析対象

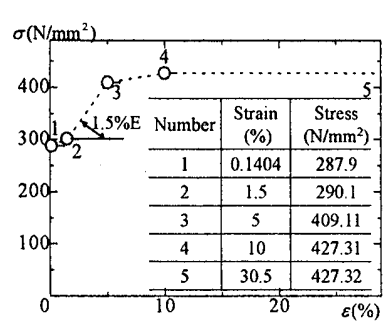

図 12 材料特性のモデル化例
表 3 解析で用いた材料特性

\begin{tabular}{|c|c|c|c|}
\hline 材料 & $\begin{array}{c}\text { 降伏強さ } \\
\left(\mathbf{N} / \mathbf{m m}^{2}\right)\end{array}$ & $\begin{array}{c}\text { 引張強さ } \\
\left(\mathbf{N} / \mathbf{m m}^{2}\right)\end{array}$ & $\begin{array}{c}\text { 伸び率 } \\
(\%)\end{array}$ \\
\hline \multirow{2}{*}{$\mathrm{H}-150 \times 150$} & 287.90 & 427.32 & 30.5 \\
& 319.82 & 441.43 & 27.8 \\
\hline \multirow{2}{*}{$\mathrm{H}-300 \times 300$} & 287.90 & 427.32 & 30.5 \\
& 319.82 & 441.43 & 27.8 \\
\hline $9 \mathrm{~mm}$ 銅板 & 305.00 & 460.10 & 26.0 \\
\hline $6 \mathrm{~mm}$ 鋼板 & 339.00 & 460.10 & 26.0 \\
\hline
\end{tabular}

$\mathrm{H}-150 \times 150 （ \mathrm{H}-300 \times 300 ）$ 上段: フランジ 下段：ウェブ 
Case 1 柱 : H-150 $150 \times 7 \times 10$ (フィレット半径 $r=8$ )

梁フランジ幅: $B_{b}=23,40,60,80,100,120,140,150 \mathrm{~mm}$,

梁フランジの厚さ $t_{b}=22,19,12,9 \mathrm{~mm}$, スチフナの厚さ $t_{s}=6,9 \mathrm{~mm}$ 各パラメタの組み合わせによる計 56 個のモデル（表 4)

Case 2 柱 : H-300 $300 \times 10 \times 15$ (フィレット半径 $r=13$ )

梁フランジ幅: $B_{b}=36,60,80,100,120,140,160,180,200,220,240$, $260,280,300 \mathrm{~mm}$,

梁フランジの厚さ $t_{b}=32,28,22,16 \mathrm{~mm}$, スチフナの厚さ $t_{s}=6,9 \mathrm{~mm}$ 各パラメタの組み合わせによる計 112 個のモデル（表 5)

FEM 解析モデル記号の表示方法 :

表示法 1：(解析ケース) - (解析モデル)

表示法 2：(解析ケース) - (解析モデル) - (梁フランジ幅)

解析モデル記号の例 :

Case 1-model 7 : Case 1 の model 7 の解析グループ (梁フランジ幅が 異なる計 8 個のモデル群)
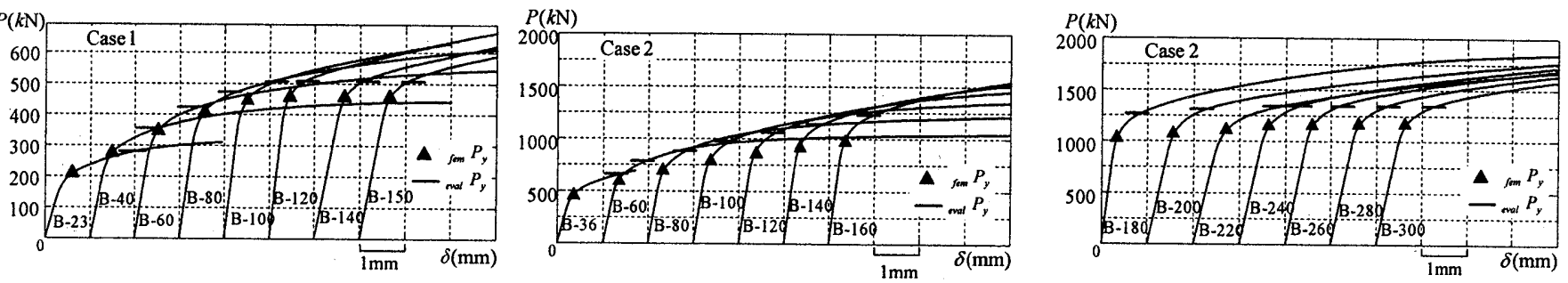

図 14 Case 2-model 8 の荷重〜変形関保曲線

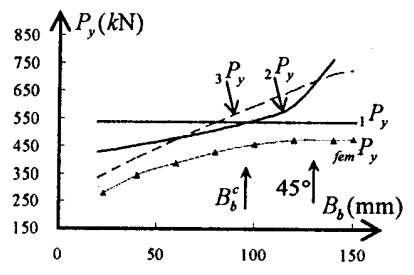

(a) Case 1-model 1

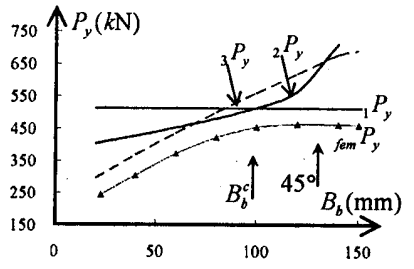

(e) Case 1-model 5

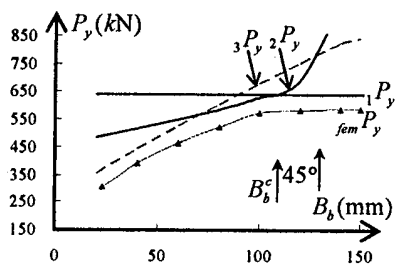

(b) Case 1-mode 2

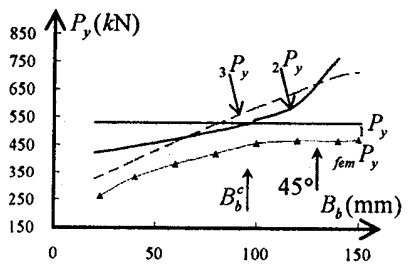

(c) Case 1-model 3

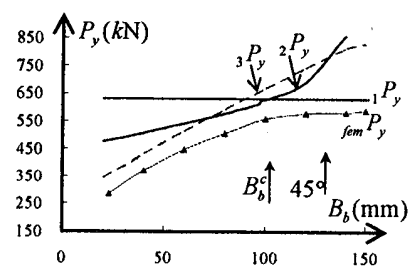

(d) Case 1-model 4

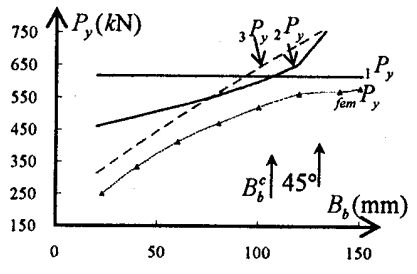

(f) Case 1-model 6

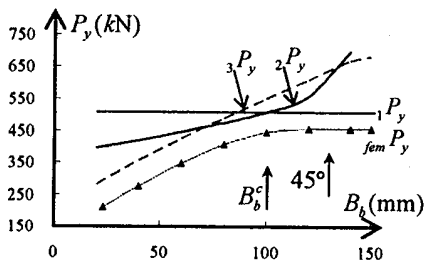

(g) Case 1-model 7

图 15 降伏耐カ〜梁フランジ幅関係 (Case 1)

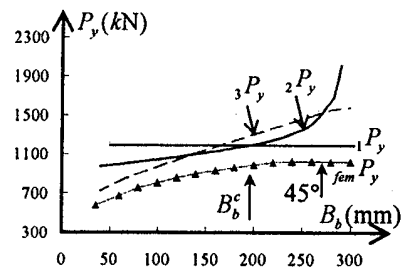

(a) Case 2-model 1

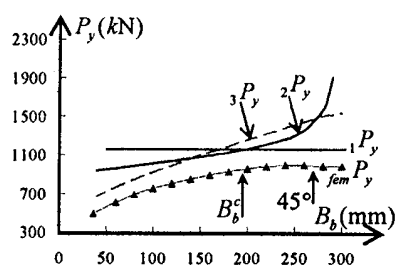

(e) Case 2-model 5

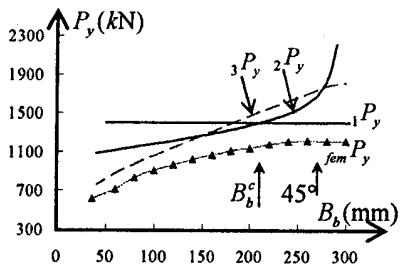

(b) Case 2-model 2

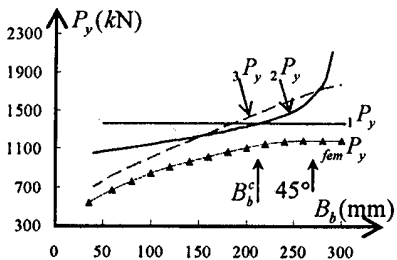

(f) Case2-model 6

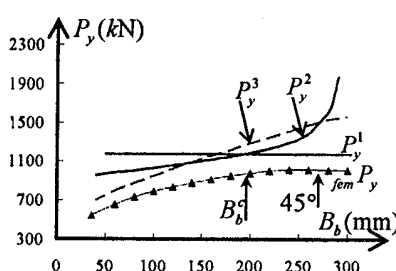

(c) Case 2-model 3

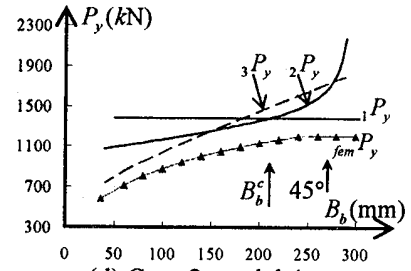

(d) Case 2-model 4

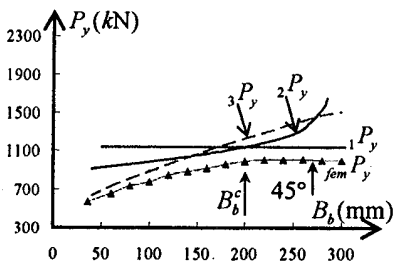

(g) Case 2-model 7

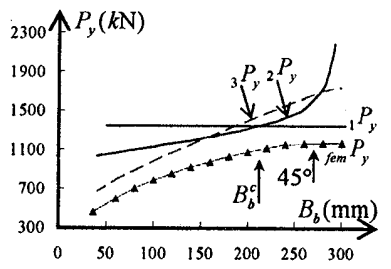

(h) Case2-model 8

図 16 降伏耐力〜梁フランジ幅関係 (Case 2) 


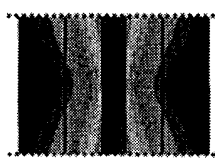

(a) model l-B-150

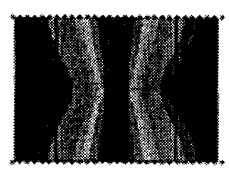

(b)model 2-B-140

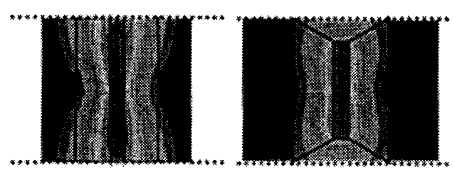

(c) model $3-\mathrm{B}-120$

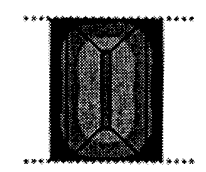

(e) model 7-B-80

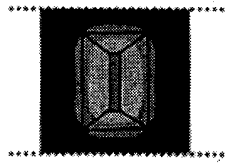

(f) model 5-B-60

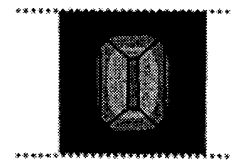

(g) model 6-B-60

图 17 解析終了㭙の面外変形等高線と予想降伏線 (Case 1)

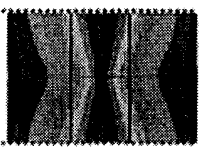

(a) model I-B-300

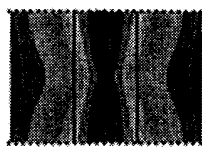

(b) model 2-B-260

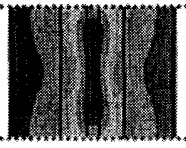

(c) model 3-B-220

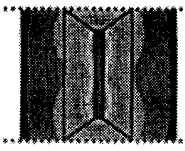

(d) model 8-B-200

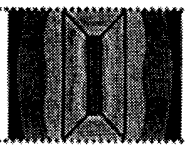

(e) model 4-B-180

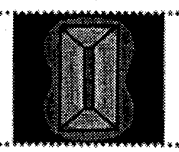

(f) model 5-B-140

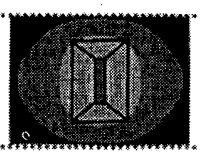

(g) model 6-B-100

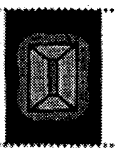

(h) model 7-B-80

图 18 解析終了時の面外変形等高線と予想降伏線 (Case 2)

おいて，接線剛性が初期剛性の $1 / 3$ となる荷重を降伏荷重 ${ }_{f e m} P_{y}$ で表 し図中に示す。評価レベル eval $_{y}$ も重社て描く。図より，いずれのケ 一スも耐力評価值 eval $_{y} P_{y}$ は降伏荷重 ${ }_{s e m} P_{y}$ よりある程度高いが, 梁フラ ンジ幅減少による降伏耐力の低下が評価できている。

\subsection{2 降伏耐カ〜梁フランジ幅の関係}

降伏耐力の評価值 ${ }_{1} P_{y} \sim{ }_{3} P_{y}$ と降伏荷重 ${ }_{j e m} P_{y}$ について, 梁フランジ 幅との関係を図 15 （Case 1）および図 16 （Case 2）に示す。多少高 く評価しているものの，3 つの評価曲線が降伏荷重を良好に包絡し ており，梁フランジ幅の減少による耐力の堿少，特に耐力減少が始 まる限界フランジ幅が評価できていることが確認できる。

ここで, 図 1(b)に示した従来用いられている45 度方向への応力伝 達の仮定について検討する。この仮定の下では, 梁フランジ幅が, Case 1 では $130 \mathrm{~mm}$, Case 2 では $270 \mathrm{~mm}$ より小さい場合に耐力低下 を考虑することになる。図 15 および図 16 中にこの寸法のレベルを $45^{\circ}$ と表示するとともに，式(28)により定まる機構 1 と機構 2 の境 界を表す梁フランジ幅 $B_{b}{ }^{\mathrm{c}}$ を図中に示す。両者を比較するといずれ のケースにおいても， $B_{b}{ }^{\mathrm{c}}$ の方が $45^{\circ}$ よりも小さいことが分かる。

\section{3.3 解析終了時の面外変形状態}

図 17 (Case 1) および図 18 (Case 2) は，解析終了時の面外変形 等高線に，降伏線理論により予想される降伏線位置を太い実線で重 ねて描いたものである。いずれのケースにおいても，変形の範囲が 異なるものの, 想定した崩壊機構と類似した変形状態が生じている ことが確認できる。図19に解析終了時の变形状態を示す。

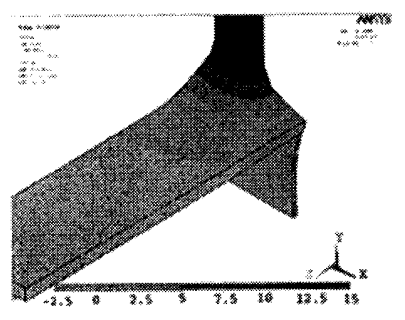

(a) Case 1-model 7-B-80

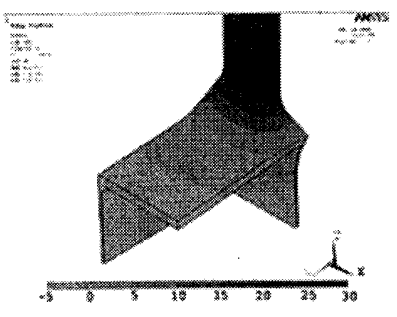

(b) Case 2-model 8-B-200
図 19 解析終了時の変形状態

\section{5 まとめ}

水平スチフナで補強された $\mathrm{H}$ 形断面柱梁接合部において梁フラン ジ幅が狭い場合，スチフナの忘力分布に偏りが生じて接合部耐力が 低下する可能性がある。本論文では, 梁フランジ幅を考慮した耐力
評価式を導出するとともに，接合部載荷実験および弾塑性有限要素 解析を行った。結論を以下にまとめる。

(1) 梁フランジ幅によって, 生じる崩壊機構を 3 つに分類すること ができ, 耐力評価值の大小関係により発生する崩壊機構が予想 できることを示した。

（2）水平スチフナ補強試験体の載荷実験を行い, 梁フランジ幅減少 により降伏耐力が低下すること，耐力評価値と実験値がよく対 态することを示した。載荷過程の柱ウェブおよびスチフナの歪 分布と実験後のフランジ面外变形を測定し，想定した崩壊機構 が妥当であることを実証した。

（3）有限要素解析を行い，梁フランジ幅減少により降伏耐力が低下 する傾向を多数のモデルに対して確認した。解析終了時の面外 変形等高線により，想定した崩壊機構が妥当であることを確認 した。

（4）耐力評価過程で評価される耐力低下が始まる限界の梁フラン ジ幅と, 梁フランジ縁から 45 度の方向への応力伝達を仮定し た場合に耐力低下を考慮する限界の梁フランジ幅を比較し，対 象としたケースでは前者の方が小さくなることを示した。 本論文では, 梁フランジ引張側接合部の局部耐力評価において, 柱軸力，接合部パネル，梁ウェブなどの影響を考虑していない。し たがって，本論文の結果を柱梁接合部の梁端曲げ耐力評価に適用す るとき，柱軸力や接合部パネル塑性化などの影響が大きい場合には 別途検討する必要がある。

\section{謝辞}

本研究の一部は，文部科学省科学研究費補助金・若手研究 B（課 題番号：18760418，研究代表者：田川浩）による。ここに記して謝 意を表する。

\section{参考文献}

1) 鋼構造設計基準, 第 4 版, 日本建築学会, 2005

2) Load and Resistance Factor Design, $2^{\text {nd }}$ Edition, Volume II, Part 10 FR Moment Connections, AISC, 1994

3) 森田耕次, 浦等, 植野良二: 柱はり接合部のスチフナ補強に関する実験的 研究，日本建築学会構造系論文報告集，第 376 号, 30-40, 1987.6

4) 渡辺貴仁, 田川浩, シベルグレル: H 形鋼柱梁接合部における水平スチフ ナ設計に関する研究, 日本建築学会大会学術講演梗概集 C-1, 構造 III, $599-600,2004.8$

5) 鋼構造塑性設計指針, 日本建築学会, 1975 
6) 仲威雄, 斎藤光 : 水平荷重を受ける柱梁接合部の実験（全溶接鉄骨構造の 耐力に関する研究一その 15)，日本建築学会論文報告集，第 66 号, 569-572, 1960.10

7) Graham JD, Shearbourne AN, Khabbaz RN, Jensen CD: Welded interior beam-to-column connections, Report for AISC, AISC, 1959

8）田川浩, 渡辺貴仁，シベルグレル：降伏線理論に基づく H 形鋼ウェブ局部 降伏の耐力評価式, 日本建等学会構造系論文集, 第 573号, 193-199, 2003.11

9) ANSYS User's manual, ver. 7.0: Swanson Analysis System, Inc., USA, 2003

10) 劉翠平, 田川浩: 梁フランジ幅が $\mathrm{H}$ 形断面柱スチフナ補強部の降伏耐力 に及ぼす影響, 日本建築学会大会学術講演梗概集 C-1, 構造 III, 757-758, 2005.9

11) 劉翠平, 田川浩: 梁フランジ幅を考㥷した $\mathrm{H}$ 形断面柱スチフナ補強部の 降伏耐力に関する実験的研究，日本建築学会東海支部研究報告集，第 44 号， 205-208, 2006.2

\section{付録 耐力評価之实験結果の比较}

本論で展開した降伏線理論は降伏荷重の上界を示すものであり，導出した 耐力評価式は真の降伏荷重よりも高く評価する。それに対して，3節で行った 実験では降伏荷重を同程度か僅かではあるが低く評価した。その理由として, 耐力評価式の導出過程において，スチフナ隅肉溶接および柱フランジ降伏線 と交差するフィレットの影響を考慮していないことが考えられる。これらに ついて，本論文で用いた試験体に対して検討した結果を以下に示す。

\section{隅肉溶接の影躈}

スチフナを隅肉溶接でウェブに取り付ける場合，図 2 のいずれの崩壊機構 においても, 柱ウェブの塑性変形に伴い，隅肉溶接も塑性変形する。隅肉溶 接部の耐力評伍式を導出するため, 図 A-1 に示す隅肉溶接の降伏場を想定す る。このとき，隅肉溶接のサイズを $w$ ，降伏強さを $\sigma_{y s}$ で表すと，隅肉溶接は 4 箇所あることから，仮想変位 $\delta$ をえたときの隅肉溶接降伏場の内力仕事は $2 w^{2} \sigma_{y s} \delta$ となる。よって, 隅肉溶接による耐力上昇の合計は次式で表される。 $\Delta P_{s}=2 w^{2} \sigma_{y s}$

(A.1)

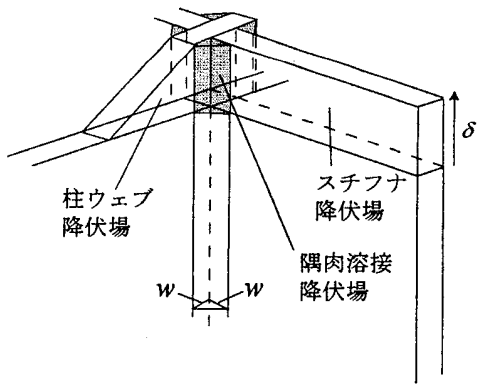

图 A-1 隅肉溶接の降伏場

\section{フィレットの影響}

図 A-2(a)に，崩壊機構における柱フランジ断面および柱ウェブを示す。こ の図に示すように，柱ウェブの降伏場はフィレット先端よりも下の領域に生 じる。よって，柱フランジに生じる降伏線が柱ウェブと交差する部分におい ては，降伏線にフィレットも含まれる。フィレット部の降伏線の厚さは，同 (b)図に示寸ように座標を考えると，BB'部分において， $t(x)=t_{f}+r-\sqrt{r^{2}-x^{2}}$

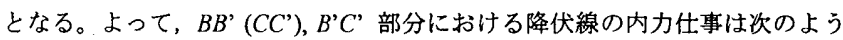
になる。なお，左上添え字の I は 2 節で検討したフィレットを考痣しない場 合を，IIはフィレットを考虑する場合を表す。 $\theta$ は降伏線の回転角である。

$$
\begin{aligned}
& { }^{1 "} E_{B B^{\prime}}^{\prime n}=\theta M=\theta\left\{\int_{0}^{r} \frac{\sigma_{y}(t(x))^{2}}{4} d x\right\} \\
& =\theta\left\{\int_{0}^{r} \frac{\sigma_{y}\left(t_{f}+r-\sqrt{r^{2}-x^{2}}\right)^{2}}{4} d x\right\} \\
& =\theta\left\{\frac{1}{4} \sigma_{y} t_{f}^{2} r+\frac{5}{12} \sigma_{y} r^{3}+\frac{1}{2} \sigma_{y} t_{f} r^{2}-\frac{\pi}{8} \sigma_{y} r^{2}\left(r+t_{f}\right)\right\}
\end{aligned}
$$

$$
\begin{aligned}
& { }^{\mathrm{I}} E_{B B^{\prime}}^{i n}=\theta M=\theta\left(\int_{0}^{r} \frac{\sigma_{y} t_{f}^{2}}{4} d x\right)=\theta\left(\frac{1}{4} \sigma_{y} t_{f}{ }^{2} r\right) \\
& { }^{\mathrm{II}} E_{B B^{\prime}}^{i n}{ }^{\mathrm{I}} E_{B B^{\prime}}^{i n}=\theta M=\theta\left\{\frac{1}{2} \sigma_{y} t_{f} r^{2}+\frac{5}{12} \sigma_{y} r^{3}-\frac{\pi}{8} \sigma_{y} r^{2}\left(r+t_{f}\right)\right\} \\
& { }^{\mathrm{II}} E_{B^{\prime} C^{\prime}}^{i n}=\theta M=\theta\left(\int_{0}^{t_{w}} \frac{\sigma_{y}\left(t_{f}+r\right)^{2}}{4} d x\right)=\theta\left(\frac{\sigma_{y} t_{w}\left(t_{f}+r\right)^{2}}{4}\right) \\
& { }^{\mathrm{I}} E_{B^{\prime} C^{\prime}}^{i n}=\theta M=\theta\left(\int_{0}^{t_{w}} \frac{\sigma_{y} r^{2}}{4} d x\right)=\theta\left(\frac{\sigma_{y} t_{w} r^{2}}{4}\right) \\
& { }^{\mathrm{II}} E_{B C^{\prime}}^{i n}-{ }^{\mathrm{I}} E_{B C^{\prime}}^{i n}=\theta M=\theta\left(\frac{1}{4} \sigma_{y} t_{w} t_{f}{ }^{2}+\frac{1}{2} \sigma_{y} t_{w} t_{f} r\right)
\end{aligned}
$$

式（A.2）〜（A.7）によりフィレットの塑性変形を考㢝することにより增加 する内力仕事は次式になる。

$$
E_{f}^{i n}=4 \theta\left\{\sigma_{y} t_{f} r^{2}+\frac{5}{6} \sigma_{y} r^{3}-\frac{\pi}{4} \sigma_{y} r^{2}\left(r+t_{f}\right)+\frac{1}{4} \sigma_{y} t_{w} t_{f}{ }^{2}+\frac{1}{2} \sigma_{y} t_{w} t_{f} r\right\}
$$

仮想仕事の原理より，フィレットの塑性変形を考慮することにより增加する 耐力 $\Delta P_{f}$ は，機構 1〜機構 3 について，それぞれ次のように評価される。

$$
\begin{aligned}
& \Delta_{1} P_{f}=\frac{4}{\gamma}\left\{\sigma_{y} t_{f} r^{2}+\frac{5}{6} \sigma_{y} r^{3}-\frac{\pi}{4} \sigma_{y} r^{2}\left(r+t_{f}\right)+\frac{1}{4} \sigma_{y} t_{w} t_{f}^{2}+\frac{1}{2} \sigma_{y} t_{w} t_{f} r\right\} \\
& \Delta_{2} P_{f}=\frac{4}{x}\left\{\sigma_{y} t_{f} r^{2}+\frac{5}{6} \sigma_{y} r^{3}-\frac{\pi}{4} \sigma_{y} r^{2}\left(r+t_{f}\right)+\frac{1}{4} \sigma_{y} t_{w} t_{f}{ }^{2}+\frac{1}{2} \sigma_{y} t_{w} t_{f} r\right\} \\
& \Delta_{3} P_{f}=\frac{4}{\alpha}\left\{\sigma_{y} t_{f} r^{2}+\frac{5}{6} \sigma_{y} r^{3}-\frac{\pi}{4} \sigma_{y} r^{2}\left(r+t_{f}\right)+\frac{1}{4} \sigma_{y} t_{w} t_{f}{ }^{2}+\frac{1}{2} \sigma_{y} t_{w} t_{f} r\right\}
\end{aligned}
$$

ここで， $\gamma, x, \alpha$ は式(2)，式(13)，式(25)を用いる。

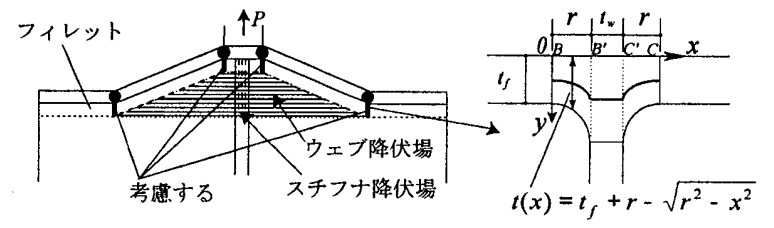

(a) 崩壊機構

(b)フィレット部の降伏線厚さ

図A-2 フィレットの影響

\section{耐力評価値の比較}

以上より，隅肉溶接および柱フィレットを考䳸して修正した耐力評価式は 次式となる。

$$
\text { eval } P_{y}^{C}={ }_{\text {eval }} P_{y}+\Delta P_{s}+\Delta P_{f}
$$

試験体 $\mathrm{A} 1 \sim \mathrm{A} 6$ について, 各耐力評価值と実験時の降伏荷重を表 A-1 にま とめる。なお, スチフナの隅肉溶接には，溶接材料としてYGW-11 を用いた。 ミルシートに示されている溶接金属の降伏強さは JIS で規定された溶接条件 下で得たものであり，ここで対象とする隅肉溶接の溶接条件下とは降伏強さ が異なるが,ここでは参考值としてミルシート值 $515 \mathrm{~N} / \mathrm{mm}^{2}$ を用いた。表 $\mathrm{A}-1$ より，隅肉溶接およびフィレットを考慮して得られた耐力評価値 $e_{\text {eval }} P_{y}^{\mathrm{C}}$ は実 験時における降伏耐力よりも大きな值となることが確認できる。

表 A-1 耐力の比較

\begin{tabular}{|c|c|c|c|c|c|}
\hline 試験体 & $\begin{array}{c}\text { 評価値 } \\
\text { eval } P_{y} \\
(k \mathrm{~N})\end{array}$ & $\begin{array}{c}\Delta P_{s} \\
(k \mathrm{~N})\end{array}$ & $\begin{array}{c}\Delta P_{f} \\
(k \mathrm{~N})\end{array}$ & $\begin{array}{c}\text { 修正值 } \\
\text { eval }^{\mathrm{P}} P_{y}^{\mathrm{C}} \\
(\mathrm{kN})\end{array}$ & $\begin{array}{c}\text { 実験值 } \\
\text { iess } P_{y} \\
(k \mathrm{~N})\end{array}$ \\
\hline $\mathrm{A}-1$ & 532.4 & 37.1 & 28.3 & 597.7 & 550 \\
\hline $\mathrm{A}-2$ & 566.2 & 37.1 & 18.5 & 621.8 & 577 \\
\hline $\mathrm{A}-3$ & 600.5 & 37.1 & 19.3 & 656.8 & 593 \\
\hline $\mathrm{A}-4$ & 569.5 & 37.1 & 16.0 & 615.6 & 583 \\
\hline $\mathrm{A}-5$ & 569.5 & 37.1 & 16.0 & 615.6 & 581 \\
\hline $\mathrm{A}-6$ & 569.5 & 37.1 & 16.0 & 615.6 & 578 \\
\hline
\end{tabular}

（2006年 7 月 5 日原稿受理，2006年12月14日採用決定） 